\title{
The Impact of Growth-Promoting Streptomycetes Isolated from Rhizosphere and Bulk Soil on Oilseed Rape (Brassica napus L.) Growth Parameters
}

\author{
Renata Cinkocki *, Nikola Lipková, Soňa Javoreková, Jana Petrová, Jana Maková, Juraj Medo and Ladislav Ducsay \\ Trieda Andreja Hlinku 2, Faculty of Biotechnology and Food Science, Slovak University of Agriculture in Nitra, \\ 94901 Nitra, Slovakia; xhricakova@is.uniag.sk (N.L.); sona.javorekova@uniag.sk (S.J.); \\ jana.petrova@uniag.sk (J.P.); jana.makova@uniag.sk (J.M.); juraj.medo@uniag.sk (J.M.); \\ ladislav.ducsay@uniag.sk (L.D.) \\ * Correspondence: xcinkocki@uniag.sk
}

check for updates

Citation: Cinkocki, R.; Lipková, N.; Javoreková, S.; Petrová, J.; Maková, J.; Medo, J.; Ducsay, L. The Impact of Growth-Promoting Streptomycetes Isolated from Rhizosphere and Bulk Soil on Oilseed Rape (Brassica napus L.) Growth Parameters. Sustainability 2021, 13, 5704. https://doi.org/ 10.3390/su13105704

Academic Editor: Andrea Pezzuolo

Received: 19 April 2021

Accepted: 17 May 2021

Published: 19 May 2021

Publisher's Note: MDPI stays neutral with regard to jurisdictional claims in published maps and institutional affiliations.

Copyright: (c) 2021 by the authors. Licensee MDPI, Basel, Switzerland. This article is an open access article distributed under the terms and conditions of the Creative Commons Attribution (CC BY) license (https:/ / creativecommons.org/licenses/by/ $4.0 /)$.

\begin{abstract}
Inoculation of Streptomyces to improve oilseed rape (Brassica napus L.) yields and minimise the use of chemical fertilisers is a promising sustainable strategy. In this study, we isolated 72 actinobacterial strains from rhizosphere of oilseed rape and maize and from bulk soil for screening and characterising their antimicrobial activity. Nine promising strains, identified as Streptomyces sp. by morphology, physiological characteristics, and 16S rRNA gene sequencing, were selected for their plant growth-promoting traits and in planta experiments. The actinobacterial strains were positive for IAA production, siderophore production, and HCN production. In planta experiments were conducted by soaking the oilseed rape seeds in the actinobacterial suspension, followed by plant growth under controlled conditions in a cultivate chamber $\left(22-28^{\circ} \mathrm{C}, 8 \mathrm{~h}\right.$ dark $/ 16 \mathrm{~h} \mathrm{light}$, constant humidity $80 \%)$. We recorded root and shoot length $(\mathrm{cm})$ and seedling fresh weight $(\mathrm{g})$. For most of the abovementioned parameters, a significant enhancement was observed with strain KmiRC20A118 treatment. The length of the root increased by $53.14 \%$, the shoot length increased by $65.6 \%$, and the weight of the fresh plant by $60 \%$ compared to the control. The integrated application of PGPS (Plant Growth Promoting Streptomyces) from the rhizosphere of oilseed rape is a promising strategy to improve the growth of oilseed rape.
\end{abstract}

Keywords: Streptomyces; PGPS; oilseed rape

\section{Introduction}

Oilseed rape (Brassica napus L.) is one of the valuable oilseed crops. It has been attracting attention in recent years as an important oil-producing plant [1] and as an alternative renewable energy source [2]. Due to the changes in temperature, rainfall, and other climatic conditions, various plant diseases have occurred on rapeseed plants in recent years, reducing their fertility [3]. Among the most important diseases are white rot (Sclerotinia sclerotiorum), stem cancer (Leptosphaeria maculans), alternarium spot (Alternaria brassicae) and grey mould (Botrytis cinerea) [4]. Oilseed rape plants lack resistance to most soil-borne pathogens and are therefore reliant on microbial-based defence mechanisms for their survival [5]. Beneficial plant-associated microorganisms are a valuable resource for the development of biological control agents and plant growth-promoting rhizobacteria (PGPR) [6]. Actinobacteria are one of the five most dominant bacterial phyla in soils and an important part of the microbial communities in both the rhizospheric and endospheric compartments of plant roots [7]. Actinobacteria are associated with the biological control of insect pests and pathogens, stress tolerance and growth promotion in plants [8]. Despite their popularity as biocontrol agents and their effectiveness in plant root system colonisation, it is surprising that they have not been adequately studied as plant growth promoters [9]. Streptomyces strains have evolved numerous potential mechanisms to directly stimulate plant growth, but in planta validation of these mechanisms is largely 
lacking, although necessary as confirmation of their direct involvement in plant growth promotion [10]. There are several studies that have suggested that the application of rhizospheric actinomycetes isolated from different crops will significantly affect the growth of oilseed rape [11,12]. Some authors have also claimed that the growth of oilseed rape is influenced by bacterial strains which are isolated from oilseed rape and subsequently applied to it [13]. The in vivo application of actinomycetes to oilseed rape is mainly being tested to reduce phytopathogenic fungi [14-16], and not many studies are available to support rapeseed growth.

In this context, we hypothesised that the strain of Streptomyces isolated from the rhizosphere of oilseed rape (Brassica napus L.) promote oilseed rape growth under controlled conditions significantly more than strains from the rhizosphere of maize and bulk soil.

\section{Materials and Methods}

\subsection{Isolation and Identification of Actinobacterial Strains}

We collected 15 samples of rhizosphere soil of maize (genotype KESSOS) and the same number of samples of rhizosphere soil of oilseed rape (genotype SIDNEY) and of bulk soil. Soil samples were collected from fields at the university farm of the Slovak University of Agriculture (SUA) in Kolínany ( $48^{\circ} 21^{\prime} 33^{\prime \prime} \mathrm{N}, 18^{\circ} 11^{\prime} 28^{\prime \prime}$ E). According to the FAO classification, the soil type was haplic luvisol with a low to medium humus content $(1.91 \%)$, an extremely low total nitrogen content $(0.19 \%)$, and a neutral $\mathrm{pH} / \mathrm{H}_{2} \mathrm{O}(7.32)$ soil reaction. Soil samples were collected randomly from different locations of a field plot and conveyed to the laboratory in coolers. Rhizospheric actinobacteria were isolated as previously described [17]. Isolation and culturing of actinomycetes were performed by the serial dilution method $\left(10^{-2}-10^{-4}\right)$ and the spread plate technique on starch-casein medium (starch $10 \mathrm{~g} / \mathrm{L}$, casein $1 \mathrm{~g} / \mathrm{L}, \mathrm{K}_{2} \mathrm{HPO}_{4} 0.5 \mathrm{~g} / \mathrm{L}$, agar $13 \mathrm{~g} / \mathrm{L}$ ) [18] supplemented with cycloheximide $(1 \mathrm{mg} / \mathrm{mL})$. The plates were incubated at $30{ }^{\circ} \mathrm{C}$ for 7 days. Powdered colonies were picked up, transferred to ISP2 medium [19], and purified several times. To select Streptomyces-like bacteria, microscopic and macroscopic characteristics of the obtained colonies were assessed, resulting in a total of 72 isolates which were further purified and sub-cultured. We isolated 21 strains from the rhizosphere of oilseed rape, 17 strains from the rhizosphere of maize, and 34 strains from the bulk soil. Single colonies were characterised by their macroscopic morphology (colours of aerial and substrate mycelium, soluble pigments and melanin) on International Streptomyces Project media (ISP2-ISP7). Physiological characteristics included the use of different carbon sources (glucose, arabinose, inositol, cellulose, mannose, fructose, galactose, rhamnose, sucrose, xylose) on ISP9 medium with final concentration of carbon sources adjusted to $1 \%$. Nutrient medium without the addition of any carbon source was used as a negative control, and glucose-supplemented medium was used as a positive control. The assay was performed in 12-well microplates. Results of these assays were used in poly-phasic identification of strains.

\subsection{Antimicrobial Activity Assay}

The 72 streptomycetes strains were tested against 7 fungal pathogens and 4 bacterial plant pathogens that may be potentially pathogenic to oilseed rape. We tested Fusarium poae (KmiZM16H007), Penicillium expansum (KmiZB20H050), Alternaria tennuissima (KmiZM16H036), Aspergillus niger (KmiLR18H120), Sclerotinia sclerotiorum (KmiJM18H119), Rhizoctonia solani (KmiJM18H121) and Leptosphaeria maculans (KmiRC20H107), obtained from the Collection of Microorganisms of the Department of Microbiology, FBF, SUA, Nitra. For this assay, fungal strains were grown on Potato Dextrose Agar (PDA) plates for 3 days at $25^{\circ} \mathrm{C}$, and two 6-mm disks of mycelium from each phytopathogenic fungus were then placed on opposites edges of a new PDA plate. Following fungal inoculation, two 6-mm wells were opened on opposite sides of the PDA plate, containing $50 \mu \mathrm{L}$ of a 5-day culture for each actinobacteria strain grown on ISP-2 medium. The plates were incubated at $28^{\circ} \mathrm{C}$ for 5 days, and antagonistic activity was estimated by measuring the growth inhibition 
zone. Antibacterial activity was tested against four bacterial plant pathogens, namely, Xanthomonas campestris (CCM 22), Pseudomonas syringae (CCM 2868), Erwinia amylovora (CCM 1114), and Clavibacter michiganesis subsp. sepedonicus (CCM 7014), obtained from the Czech Collection of Microorganisms.

Six-hour-old cultures of the tested bacteria in Mueller-Hinton (MH) broth were used for antimicrobial activity assessment. Bacterial cultures were diluted to $0.05 \mathrm{McF}$ arland standard turbidity using MH and then were spread onto the surfaces on TSA (Tryptone Soya Agar) plates using sterile bacterial cell spreaders. Six millimetre disks of mycelium from each actinobacterial strain were placed in the centre of each plate [20]. Plates were incubated at $30^{\circ} \mathrm{C}$, and the inhibition zones were determined after $24 \mathrm{~h}$. Based on antimicrobial activity, we selected the nine most active strains for further testing. Three strains were selected from the rhizosphere of maize, three from the rhizosphere of oilseed rape, and three from the bulk soil (Table 1).

\subsection{Molecular Phylogeny}

Strains were inoculated on ISP-2 agar and incubated at $28 \pm 2{ }^{\circ} \mathrm{C}$. The DNA was extracted from 24-h-old actinobacterial culture. Approximately $50 \mathrm{mg}$ of actinobacterial culture was placed in $200 \mu \mathrm{L}$ of PrepMan solution (Life Technologies, CA, USA) and homogenised with glass beads in a BeadBug homogeniser (Benchmark scientific, NJ, USA). Subsequently, $1 \mu \mathrm{l}$ of the supernatant was used in the PCR (Polymerase Chain Reaction) reaction. The $16 \mathrm{~S}$ rRNA gene of the DNA was amplified by using the forward primer $27 \mathrm{~F}$ ( $5^{\prime}$-AGAGTTTGATCCTGGCTCAG-3') and the reverse primer 1492R (5'-TACGGTTACCTTGTTACGACTT-3') [21]. Thirty microliters of the PCR mixture contained $3 \mu \mathrm{L}$ of 10x Dream Taq DNA buffer, $3 \mu \mathrm{L}$ of $2 \mathrm{mM}$ dNTP mix, $1 \mu \mathrm{L}$ of $\mathrm{MgCl}_{2}, 1.2 \mu \mathrm{L}$ each of the opposing amplification primers $(10 \mathrm{mM}), 0.1 \mu \mathrm{L}$ Dream Taq DNA polymerase, and $1 \mu \mathrm{L}$ of genomic DNA. The PCR amplification was performed in a thermal-cycler MJ Mini (Biorad, CA, USA) programmed for an initial cycle at $95^{\circ} \mathrm{C}$ for $3 \mathrm{~min}$, followed by 40 cycles at $95{ }^{\circ} \mathrm{C}$ for $30 \mathrm{~s}, 56^{\circ} \mathrm{C}$ for $30 \mathrm{~s}, 72^{\circ} \mathrm{C}$ for $90 \mathrm{~s}$, followed by a final extension at $72{ }^{\circ} \mathrm{C}$ for $10 \mathrm{~min}$. The PCR-amplified $16 \mathrm{~S}$ rDNA was checked in agarose gel. Products were purified by enzymatic treatment using the ExoI/FastAP mixture (ThermoFisher, MA USA) and sequenced by the MacroGen Company, South Korea. The similarity and homology of the 16S rRNA partial gene sequence were compared with available sequences by the BLAST search against the GenBank (www.genbank.com, accessed 15 April 2021) 16S rRNA gene database, limited to type strains [22]. The DNA sequences were aligned, and the phylogenetic tree was constructed using the maximum likelihood algorithm. A bootstrap analysis of 1000 replicates was carried out using Molecular Evolutionary Genetics Analysis (MEGA) 6.06 [23].

\subsection{In-Vitro Screening of Actinobacteria Strains for Their Plant Growth-Promoting Traits \\ 2.4.1. Production of Indole-3-Acetic Acid (IAA)}

The production of indole-3-acetic acid was quantified using a method described previously [24]. All actinobacteria were grown in ISP-2 liquid medium with tryptophan $\left(200 \mu \mathrm{g} . \mathrm{mL}^{-1}\right)$ for 10 days at $28{ }^{\circ} \mathrm{C}$ at $120 \mathrm{rpm}$. After incubation, $5 \mathrm{~mL}$ of the culture medium was centrifuged at 10,000 rpm for $10 \mathrm{~min}$. The supernatant $(4 \mathrm{~mL})$ was mixed with $8 \mathrm{~mL}$ Salkowski reagent $\left(35 \% \mathrm{HClO}_{4}, \mathrm{FeCl}_{3}\right)$ and incubated at $25^{\circ} \mathrm{C}$ for $30 \mathrm{~min}$ in the dark. Development of a pink colour indicated IAA production, and the absorbance of the solutions was read at $530 \mathrm{~nm}$. The concentration of indole-3-acetic acid in culture was determined using a calibration curve of pure IAA as a standard, following the linear regression analysis. 
Table 1. Antimicrobial activity of isolated actinomycetes.

\begin{tabular}{|c|c|c|c|c|c|c|c|c|c|c|c|}
\hline \multirow[b]{2}{*}{$\begin{array}{l}\text { Isolation } \\
\text { Source }\end{array}$} & \multirow[b]{2}{*}{$\begin{array}{l}\text { Actinobacterial } \\
\text { Strains }\end{array}$} & \multicolumn{4}{|c|}{ Antimicrobial Activity (mm) } & \multicolumn{6}{|c|}{ Antifungal Activity (mm) } \\
\hline & & $\begin{array}{l}\text { Xantomonas } \\
\text { campestris }\end{array}$ & $\begin{array}{c}\text { Pseudomonas } \\
\text { syringae }\end{array}$ & $\begin{array}{l}\text { Erwinia } \\
\text { amylovora }\end{array}$ & $\begin{array}{l}\text { Clavibacter } \\
\text { michiganesis }\end{array}$ & $\begin{array}{l}\text { Fusarium } \\
\text { poae }\end{array}$ & $\begin{array}{l}\text { Penicillium } \\
\text { expansum }\end{array}$ & $\begin{array}{l}\text { Alternaria } \\
\text { tennuissima }\end{array}$ & $\begin{array}{l}\text { Aspergilus } \\
\text { niger }\end{array}$ & $\begin{array}{l}\text { Sslerotinia } \\
\text { sclerotiorum }\end{array}$ & $\begin{array}{l}\text { Leptosphaeria } \\
\text { maculans }\end{array}$ \\
\hline \multirow{3}{*}{$\begin{array}{l}\text { Rhizosphere } \\
\text { of maize }\end{array}$} & $\begin{array}{c}\text { Kmi } \\
\text { SK16A002 }\end{array}$ & 16 & 13 & 0 & 48 & 21 & 30 & 44 & 25 & 40 & 14 \\
\hline & $\begin{array}{c}\text { Kmi } \\
\text { SK16A004 }\end{array}$ & 24 & 13 & 16 & 44 & 0 & 11 & 36 & 0 & 0 & 28 \\
\hline & $\begin{array}{c}\text { Kmi } \\
\text { SK16A006 }\end{array}$ & 20 & 0 & 17 & 50 & 0 & 22 & 28 & 15 & 45 & 0 \\
\hline \multirow{3}{*}{ Bulk soil } & $\begin{array}{c}\text { Kmi } \\
\text { ICH17A011 }\end{array}$ & 0 & 0 & 0 & 26 & 18 & 29 & 0 & 26 & 17 & 31 \\
\hline & $\begin{array}{c}\text { Kmi } \\
\text { ICH17A097 }\end{array}$ & 15 & 14 & 15 & 31 & 17 & 23 & 0 & 18 & 0 & 19 \\
\hline & $\begin{array}{c}\text { Kmi } \\
\text { ICH17A098 }\end{array}$ & 16 & 14 & 14 & 28 & 32 & 24 & 0 & 0 & 15 & 21 \\
\hline \multirow{3}{*}{$\begin{array}{c}\text { Rhizosphere } \\
\text { of oilseed } \\
\text { rape }\end{array}$} & $\begin{array}{c}\text { Kmi } \\
\text { RC20A118 }\end{array}$ & 22 & 0 & 0 & 42 & 16 & 14 & 12 & 10 & 0 & 41 \\
\hline & $\begin{array}{c}\text { Kmi } \\
\text { RC20A119 }\end{array}$ & 0 & 12 & 9 & 35 & 0 & 0 & 25 & 0 & 35 & 29 \\
\hline & $\begin{array}{c}\mathrm{Kmi} \\
\text { RC20A120 }\end{array}$ & 24 & 0 & 10 & 39 & 15 & 8 & 45 & 0 & 28 & 37 \\
\hline
\end{tabular}




\subsubsection{Siderophore Production}

The production of siderophores was qualified by Universal Chrome Azurol S (CAS) [25]. The actinobacterial strains were spot-inoculated on CAS agar and incubated for 7 days at $28^{\circ} \mathrm{C}$. Orange or yellow halo zones around the colony indicated siderophore production.

\subsubsection{Phosphate Solubilisation}

Actinobacteria strains were spot-inoculated on Pikovskaya agar [26] under aseptic conditions and incubated for 7 days at $28{ }^{\circ} \mathrm{C}$. The clear zones around the colony were considered phosphate solubilisers. The phosphate solubilisation index (PSI) was calculated according to the following formula [27]:

$$
\text { PSI }=\frac{\text { Colony diameter }+ \text { Diameter of halo zone }}{\text { Colony diameter }}
$$

\subsubsection{Production of Hydrogen Cyanide (HCN)}

Actinobacteria were spot-inoculated on ISP-2 medium and filter paper-dipped in the $2 \%$ sodium carbonate and in the $0.5 \%$ picric acid for $1 \mathrm{~min}$; the filter paper was then placed on the media surface. Plates were incubated for 7 days at $28^{\circ} \mathrm{C}$. On orange to red colour of the filter indicated $\mathrm{HCN}$ production $[28,29]$.

\subsection{In-Situ Screening of Actinobacterial Strains for Their Plant Growth-Promoting Traits}

\subsubsection{Germination Test}

The germination assay was conducted according to the protocols described for the standard germination test (Association of Official Seed Analysis, 1993). Groups of 100 rapeseed (Brassica napus L.) seeds were placed in a Petri dish with filter paper (Whatman No. 4) and moistened with sterile distilled water. Testing lasted for 7 days at $25^{\circ} \mathrm{C}$. Germination rate achieved $99 \%$.

\subsubsection{Preparation of Actinobacterial Inocula}

To prepare the actinobacterial cultures, each bacterial strain was grown in a $250-\mathrm{mL}$ flask containing $100 \mathrm{~mL}$ ISP-2 medium and incubated for $48 \mathrm{~h}$ at $28^{\circ} \mathrm{C}$. After incubation, actinomycetes were subsequently inoculated on the ISP-2 plates and cultivated at $28^{\circ} \mathrm{C}$ for 5 days. The sporulated actinomycetes were scraped, poured into sterile distilled water, and filtered. The concentrations were standardised to $5 \times 10^{8} \mathrm{CFU} \cdot \mathrm{mL}^{-1}$ [30]. Oilseed rape seeds were sterilised as described elsewhere [31]. After sterilisation, seeds were soaked on spore suspension for $45 \mathrm{~min}$ with constant shaking at $120 \mathrm{rpm}$. For the control, the seeds were dipped in sterile distilled water.

\subsubsection{In-Situ Experiment}

This experiment was performed in sterile soil (haplic luvisol, humus content $1.91 \%$, nitrogen content $0.19 \%, \mathrm{pH} / \mathrm{H}_{2} \mathrm{O}$ 7.32). Actinobacterial-treated oilseed rape (genotype SYNDEY) seeds were placed in plastic pots with $200 \mathrm{~g}$ sterile soil to a depth of $1 \mathrm{~cm}$. The soil was sterilised in an autoclave under the following conditions: pressure $0.1 \mathrm{MPa}$ and temperature $121^{\circ} \mathrm{C}$ for $20 \mathrm{~min}$. The seeds dipped in sterile water were used as negative control. Each treatment included two biological replicates (two independent colonies for each bacterial strain), and six seeds were inoculated with each inoculum. Oilseed rape was grown under controlled conditions in a cultivation chamber $\left(22-28^{\circ} \mathrm{C}, 8 \mathrm{~h}\right.$ dark $/ 16 \mathrm{~h} \mathrm{light}$, constant humidity $80 \%$ ). After 30 days, plants were removed from the soil, and the roots were rinsed with water. The root and shoot length and the weight of the fresh plant were measured and statistically evaluated. 


\subsubsection{Statistical Analysis}

Statistical analysis was conducted by using analysis of variance, applying the statistical program Statgraphics XV. The differences among variances were compared using the Tukey $\operatorname{HSD}(p \leq 0.05)$.

\section{Results and Discussion}

A total of 72 actinomycete strains were isolated and subjected to primary screening (antimicrobial activity). Of these, we selected the nine most active ones (three from the maize rhizosphere, three from oilseed rape rhizosphere, and three from bulk soil) based on antimicrobial activity. The tested bacteria and fungi were among the important plant pathogens of wheat, potatoes, corn, beans, oilseed rape, and many others [32,33]. For example, strain KmiSK16A006 showed significant antimicrobial activity against the oilseed rape pathogen Xanthomonas campestris (20 mm), the causal agent of black rot disease [34] and Sclerotinia sclerotiorum $(45 \mathrm{~mm})$, the agent of white stem rot [35]. Also, strains KmiICH17A011, KmiRC20A118, KmiRC20A119, and KmiRC20A120 showed significant antifungal activity against the important oilseed rape pathogen Leptosphaeria maculans, the causal agent of phoma stem canker of oilseed rape (Brassica napus L.) [36]. According to a previous study, it is important to examine actinomycetes with antibacterial and antifungal effects as producers of new bioactive products in agriculture or for direct use as biocontrol in the soil environment [37]. According to the results in Table 1, the strains of actinomycetes selected here can be potential producers of bioactive substances important for the protection of oilseed rape from microbial pathogens $[9,38,39]$.

Diameter of the inhibition zone using the agar plug method excluding the diameter of Streptomyces agar block $(6 \mathrm{~mm})$.

\subsection{Characterisation of Actinomycete strains}

Based on the morphological, physiological, and genotypic features, we characterised and identified all nine strains of actinomycetes (Tables 2 and 3). We confirmed that these are species of the genus Streptomyces, the most common genus in the soil. All strains were characterised based on 16S rRNA gene sequences and cultural taxonomy procedure. The dendrogram of the nine strains indicates species relatedness. The phylogenetic comparison of sequences with the 16s rRNA NCBI database limited to type species using the BLASTn is shown in Figure 1. For the correct identification of strains, we also compared all strains according to the available data presented in the Compendium of Actinobacteria [40]. Several type species (5-10) with highest sequence homology to particular strain were selected and their morphological and physiological data were accessed in compendium. These data were compared to strain properties and results to most likely identification.

Table 2. Morphological characteristics of actinobacterial strains.

\begin{tabular}{|c|c|c|c|c|}
\hline $\begin{array}{c}\text { Actinobacterial } \\
\text { Strains }\end{array}$ & $\begin{array}{l}\text { Colour of Aerial } \\
\text { Mycelium }\end{array}$ & $\begin{array}{l}\text { Colour of Substrate } \\
\text { Mycelium }\end{array}$ & $\begin{array}{l}\text { Soluble } \\
\text { Pigment }\end{array}$ & $\begin{array}{c}\text { Melanoid } \\
\text { Pigment }\end{array}$ \\
\hline KmiSK16A002 & White & Yellow & - & + \\
\hline KmiSK16A004 & Green & Rusty red & Beige yellow & - \\
\hline KmiSK16A006 & Beige & Orange & - & + \\
\hline KmiICH17A011 & White & Bottle green & - & + \\
\hline KmiICH17A097 & White & Red & Olive green & + \\
\hline KmilCH17A098 & White & Ivory & Brown & - \\
\hline KmiRC20A118 & Ivory & Yellow & - & - \\
\hline KmiRC20A119 & Beige & Brown & - & + \\
\hline KmiRC20A120 & Ivory & Yellow & - & + \\
\hline
\end{tabular}


Table 3. Growth of actinobacterial strains in presence of various carbon sources.

\begin{tabular}{ccccccccccc}
\hline $\begin{array}{c}\text { Actinobacterial } \\
\text { Strains }\end{array}$ & Glucose & Xylose & Sucrose & Mannose & Arabinose & Raffinose & Inositol & Fructose & Rhamnose & Cellulose \\
\hline KmiSK16A002 & + & - & - & + & + & - & - & + & - \\
KmiSK16A004 & + & - & - & + & - & - & - & - & - \\
KmiSK16A006 & + & - & - & + & + & - & - & + & + \\
KmiICH17A011 & + & - & + & + & + & + & + & + & + \\
KmiICH17A097 & + & + & + & + & + & + & + & + & - \\
KmiICH17A098 & + & - & - & - & - & - & - & - & - \\
KmiRC20A118 & + & - & + & + & + & + & - & + & - \\
KmiRC20A119 & + & + & + & + & + & - & + & + & + \\
KmiRC20A120 & + & + & + & + & - & + & + & - & - \\
\hline
\end{tabular}

+ growth, - absence of growth.

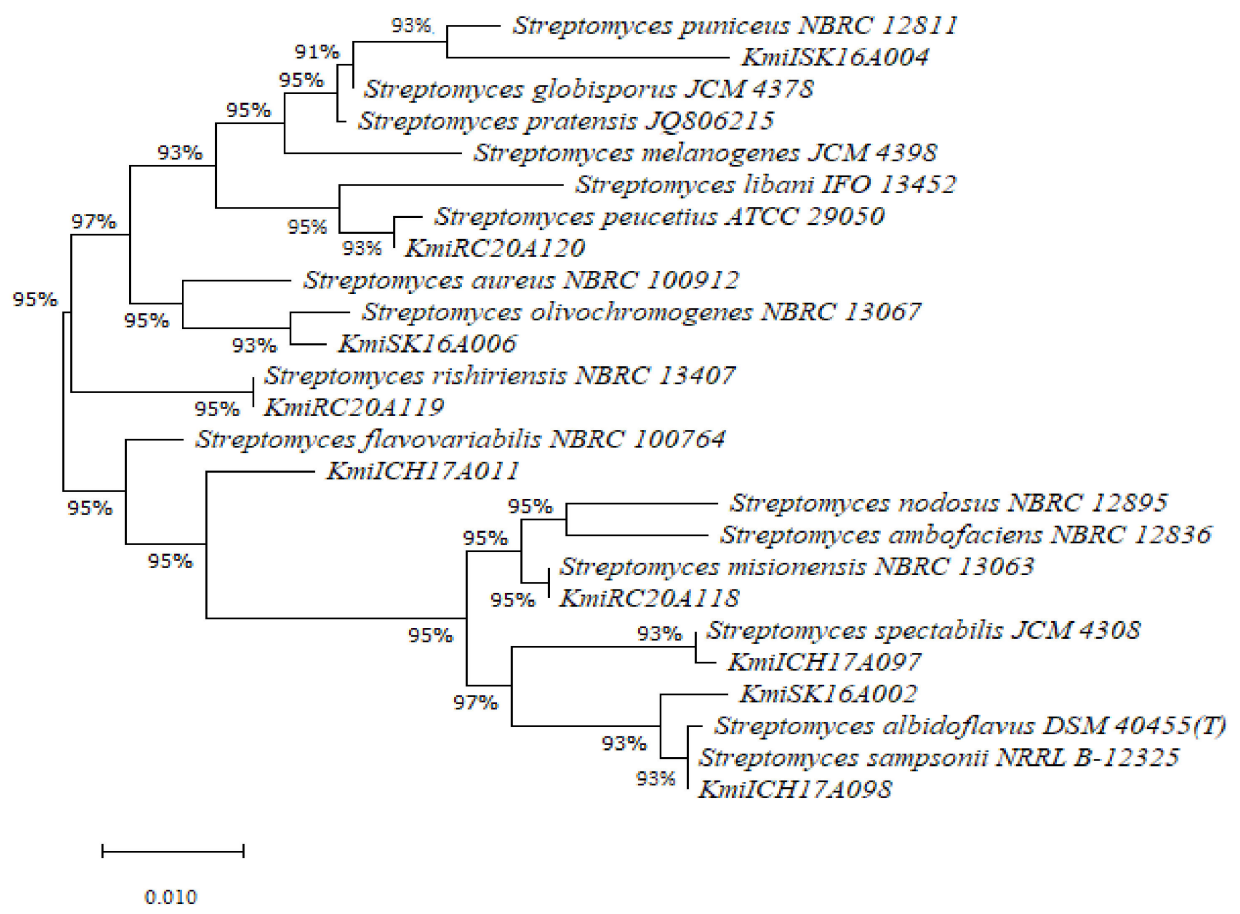

Figure 1. Phylogenetic tree based on the comparison of the $16 \mathrm{~S}$ rDNA sequences of Streptomyces sp. strains and some of their closest phylogenetic relatives. The tree was created by ML algorithm with neighbour-joining starting tree. The numbers on the tree indicate the percentages of bootstrap sampling derived from 1000 replications.

Using polyphasic identification systems actinobacterial strains were identified as Streptomyces sampsonii (KmiSK16A002), Streptomyces puniceus (KmiSK16A004), Streptomyces olivochromogenes (KmiSK16A006), Streptomyces flavovariabilis (KmiSK16A011), Streptomyces spectabilis (KmiICH17A097), Streptomyces albidoflavus (KmilCH17A098), Streptomyces misionensis (KmiRC20A118), Streptomyces rishiriensis (KmiRC20A119) and Streptomyces peucetius (KmiRC20A120). Accession numbers are shown in Table 4. According to data in the literature, all characterised species have already been confirmed as plant growth-promoting streptomycetes (PGPS). In the case of Streptomyces albidoflavus [41-43], Streptomyces sampsonii [44,45], Streptomyces puniceus [46], Streptomyces cirratus [47], Streptomyces flavovariabilis [48] and Streptomyces rishiriensis [49], there was a strong antagonistic activity against several phytopathogenic fungi such as Aspergillus niger, Microsporum gypseum, Trichopyton sp., Fusarium sp. and Alternaria solani. Strains identified as Streptomyces olivochromogenes [50], Streptomyces spectabilis [51], and Streptomyces misioensis [52] have already been confirmed as PGPS, which, in addition to antifungal activity, have also shown the ability to produce indolyl-3-acetic acid, solubilise phosphates, and produce siderophores. Streptomyces peucetius is one of the major producers of the new type of siderophores [53]. 
Table 4. GenBank accession numbers for tested Streptomyces strains, BLASTn best hit, and predicted taxonomic affiliation according polyphasic identification system.

\begin{tabular}{|c|c|c|c|}
\hline Strain & $\begin{array}{c}\text { GenBank Accessions } \\
\text { No. }\end{array}$ & BLASTn Best Hit & Polyphasic Identification \\
\hline KmiSK16A002 & MZ172903 & S. sampsonii KP096298 $(772 / 773)^{a}+1$ gap & S. sampsonii \\
\hline KmiSK16A004 & MZ172904 & S. cavourensis NR_112345.1 $(845 / 821)+3$ gaps & S. puniceus \\
\hline KmiSK16A006 & MZ172902 & S. olivochromogenes KF317983 $(646 / 651)+2$ gaps & S. olivochromogenes \\
\hline KmilCH17A011 & MZ172905 & S. pseudovenezuelae NR_114832.1 (808/821) & S. flavovariabilis \\
\hline KmilCH17A097 & MZ172906 & S. spectabilis NR_112398.1 $(1341 / 1343)+1$ gap & S. spectabilis \\
\hline KmilCH17A098 & MZ172907 & S. albidoflavus NR_041095.1 (1054/1057) + 3 gaps & S. albidoflavus \\
\hline KmiRC20A118 & MZ182311 & S. misionensis NR_044138.1 $(798 / 800)$ & S. misionensis \\
\hline KmiRC20A119 & MZ182310 & S. rishiriensis NR_112392.1 (802/802) & S. rishiriensis \\
\hline KmiRC20A120 & MZ182312 & S. peucetius NR_112574.1 $(800 / 801)+1$ gap & S. peucetius \\
\hline
\end{tabular}

${ }^{\mathrm{a}}$ homology in base pairs.

\subsection{Plant Growth Promotion Determination (IAA, Siderophore and HCN Production, Phosphate Solubilisation)}

The streptomycetes from bulk soil and rhizosphere soil were determined for their plant growth-promoting activity, phosphate solubilisation, and the production of IAA, siderophores, and HCN. These capabilities of streptomycetes are particularly important for their use as biofertilisers and biostimulants, as oilseed rape requires high amounts of biogenic elements in the soil [12]. The ability of strains to produce IAA [54] results in improved plant growth via facilitating nutrient uptake, water absorption, germination, and root elongation [55]. All tested streptomycetes strains produced IAA within a range of 8-40 $\mu \mathrm{g} \cdot \mathrm{mL}^{-1}$ (Table 5). The most active strain was KmiRC20A118, isolated from the rhizosphere of oilseed rape. Other studies have also confirmed that Streptomyces sp. can produce large amounts of IAA [56], and $11.2 \%$ of rhizosphere streptomycetes produce IAA in the range of 11-144 $\mu \mathrm{g} \mathrm{mL}^{-1}$ [57]. The amount of IAA produced depends mainly on the presence of tryptophan [58]. In the strain Streptomyces fradiae NKZ-259, the production of IAA after adding various concentrations of L-tryptophan to the culture medium was significantly affected. After the addition of $2 \mathrm{~g} \mathrm{~L}^{-1}$ tryptophan to the medium, which is the optimal amount, IAA production was $56.28 \mu \mathrm{g} \mathrm{mL}^{-1}$, whereas when five times more tryptophan was added $\left(10 \mathrm{~g} \mathrm{~L}^{-1}\right)$, the production decreased to $40.22 \mu \mathrm{g} \mathrm{mL} \mathrm{m}^{-1} \mathrm{IAA}$, indicating that higher concentrations of tryptophan in the medium can also have an adverse effect on IAA production [59].

Table 5. Plant growth-promoting traits of Actinobacteria strains.

\begin{tabular}{ccccc}
\hline Strains & $\begin{array}{c}\text { IAA Production } \\
\left(\boldsymbol{\mu g} \mathbf{~ m L}^{-\mathbf{1}} \mathbf{)}\right.\end{array}$ & $\begin{array}{c}\text { Siderophore } \\
\text { Production }\end{array}$ & $\begin{array}{c}\text { HCN } \\
\text { Production }\end{array}$ & $\begin{array}{c}\text { Phosphate } \\
\text { Solubilisation } \\
\text { Index }(\mathbf{m m})\end{array}$ \\
\hline KmiSK16A002 & $25.02 \pm 0.002$ & - & + & 0 \\
KmiSK16A004 & $30.52 \pm 0.01$ & + & + & 0 \\
KmiSK16A006 & $24.09 \pm 0.004$ & + & + & 0 \\
KmiICH17A011 & $19.32 \pm 0.002$ & + & + & 0 \\
KmiICH17A097 & $26.47 \pm 0.005$ & + & + & $11.9 \pm 0.4$ \\
KmiICH17A098 & $8.12 \pm 0.01$ & + & + & 0 \\
KmiRC20A118 & $40.34 \pm 0.004$ & + & + & $13.1 \pm 0.04$ \\
KmiRC20A119 & $25.71 \pm 0.003$ & + & + & 0 \\
KmiRC20A120 & $24.23 \pm 0.005$ & + & $12.7 \pm 0.05$ \\
\hline
\end{tabular}

Values represent mean $\pm \mathrm{SE} ;{ }^{a}$ presence of orange zone: + present; - absent; ${ }^{b}$ presence of orange-brown colour: + present; - absent.

The IAA production by streptomycetes can vary among different species and strains and is influenced by culture condition, growth stage, and substrate availability [60]. Moreover, strains from the rhizosphere are more efficient auxin producers than those from bulk soil [61]. According to our results, strains from rhizosphere soil showed high IAA production. These results are comparable with the results of a previous study [62]; the authors 
tested 12 strains of actinomycetes from the rhizosphere soils of three crop plants (wheat, maize, and faba bean), using the same methodology, and found IAA production rates between 3.54 and $22.56 \mu \mathrm{g} \mathrm{mL}^{-1}$. This is similar to the strains from bulk soil, and several studies have shown that Streptomyces sp. from various crop soils have this ability $[55,57,63]$.

Siderophore production stimulates plant growth by forming complexes with iron $\left(\mathrm{Fe}^{3+}\right)$ in the rhizosphere, making iron unavailable to the phytopathogens [29]. In our study, we detected $88 \%$ of strains to be positive for siderophore production on CAS agar (Table 5). Similarly, in a previous study [64], 87.5\% of strains from the rhizosphere soils of various crops (rice, chickpea, sorghum) and vermicompost were positive for siderophore production on CAS agar. In another study [65], Streptomyces thermolilacinus, Streptomyces rochei, and Streptomyces carpinensis showed the ability to produce siderophores on CAS agar medium. Actinomycetes, especially species of the genus Streptomyces isolated from various habitats, are the major producers of siderophores [66]; about $44 \%$ of soil actinobacteria provide positive results on chrome azurol sulphate (CAS) assay plates [67]. These findings confirm that strains from bulk soil can also produce siderophores, which is important for their potential use in agriculture.

Certain rhizosphere Streptomyces species have been reported to produce HCN [68,69]. All strains from the rhizosphere tested in this study were positive for HCN production. Strains from bulk soil also showed this ability, suggesting their potential use to support plant growth (Table 5). One study reported the production of HCN by rhizosphere Streptomyces [70]. Because of its toxicity to plant pathogens, $\mathrm{HCN}$ is recognised as a biocontrol agent [71], which is confirmed here because our strains showed excellent antimicrobial activity.

Also, actinobacteria can promote the growth of host plants by solubilising inorganic phosphate and enhancing the uptake of phosphorus by the plant when its bioavailability is low [72]. After 7 days of incubation on Pikovskaya agar, only three of the tested strains were able to solubilise phosphates based on the halo zones formed. The strain KmiICH17A097 $(11.9 \mathrm{~mm})$ from bulk soil, strain Streptomyces misionensis KmiRC20A118 (13.1 mm) and strain KmiRC20A120 (12.7 mm) from rhizosphere soil of oilseed rape showed low phosphate solubilisation index values, and we did not observe this ability in strains from the maize rhizosphere (Table 5). Similar results have been reported in studies where bacterial strains tested on Pikovskaya agar showed a low solubility index [73-75]. The ability of the same bacteria to dissolve phosphates on solid agar and liquid medium differs; some studies have found that the bacteria show a considerably higher phosphate production in liquid medium [76,77]. The low phosphate solubility index may be related to several factors, such as organic acid production or nutrient composition [76,78], but according to the available source, it is not related to origin of the strains.

\subsection{Evaluation of Streptomyces Strains for Their PGP Potential under Controlled Conditions}

Various Streptomyces strains have been described as efficient PGPS that can stimulate plant growth. Previously, researchers [79-82] have confirmed the promising effects of different PGPS species on various crops in laboratory and field experiments under varying ecological conditions. For instance, inoculation of the model plant Arabidopsis thaliana with several Streptomyces strains resulted in an increase in plant biomass [83,84]. For crops such as rice, wheat, sorghum, and tomato, an increase in biomass has been reported with several Streptomyces inoculants from rhizosphere soil [84-86]. In this study, all nine strains significantly stimulated oilseed rape growth $(p<0.05)$ in terms of root and shoot length as well as seedling weight with respect to the control (Table 6). Three strains (KmiRC20A118, KmiRC20A119, KmiRC20A120) from the rhizosphere of oilseed rape were more active compared to the control and other strains. The maximum value recorded for root length was $25.4 \mathrm{~cm}$, which was observed for KmiRC20A118, followed by $23.45 \mathrm{~cm}$ for KmiRC20A120 and $21.15 \mathrm{~cm}$ for KmiRC20A119; the minimum value was $13.5 \mathrm{~cm}$ for the control. The increase in shoot length observed for KmiRC20A118, KmiRC20A119, and KmiRC20A120 was 65.6, 38.8, and 48\%, respectively; for the remaining cultivars, shoot length ranged between 13 and 40\%. Similar results have been reported elsewhere [12], with 
a 35-40\% increase in the length of oilseed rape shoots after 3 weeks of growth in a culture chamber. Seedling weight (g.plant ${ }^{-1}$ ) was also statistically higher for KmiRC20A118, KmiRC20A119, and KmiRC20A120 compared to the control and all other strains. The increase in seedling weight was $60 \%$ for KmiRC20A118 and KmiRC20A119 in regard to the control. Such enhanced growth can be attributed to the ability of PGPS to produce plant growth regulators such as IAA $[87,88]$, which play a vital role in cell elongation, cell division, and root elongation, ultimately improving plant growth [89,90]. For some PGPR, such as Pseudomonas fluorescens and Azospirillum brasilense, analyses of both bacteria and Arabidopsis thaliana have revealed that bacterial auxin production and subsequent auxin signalling in the plant play a major role in growth promotion [91,92]. We can confirm this correlation, as the strain KmiRC20A118 produced a high amount of IAA $\left(40.34 \mu \mathrm{g} \cdot \mathrm{mL}^{-1}\right)$. The response of oilseed rape to different strains was variable, which may be attributed to their individual traits and rhizospheric competencies. The significant increase in growth caused by strains from the rhizosphere of oilseed rape clearly indicates that these bacterial strains can colonise the plant host from which they had been isolated, resulting in an increase in plant biomass. The effect of strains from maize rhizosphere and bulk soil compared to the control was significant and suggests their potential in supporting plant growth. Thus, it is important to explore and identify region-specific PGPS strains as they are most suitable for enhancing crop growth and yield in that particular region [93]. Although, to date, data on the application of actinomycetes to oilseed rape are scarce, a significant improvement in rapeseed growth parameters after inoculation with actinomycetes in the culture chamber may be evidence for the designation of actinomycete strains as PGPS strains [12].

Table 6. Effect of Streptomyces strains to promote the growth of rapeseed (Brassica napus L.).

\begin{tabular}{cccc}
\hline Treatment & Root Length $\mathbf{( c m )}$ & Shoot Length $(\mathbf{c m})$ & Seedling Weight $(\mathbf{g})$ \\
\hline CONTROL & $13.5 \pm 1.84^{\mathrm{a}}$ & $16.20 \pm 0.19^{\mathrm{a}}$ & $7.86 \pm 0.92^{\mathrm{a}}$ \\
KmiSK16A002 & $20.25 \pm 3.18^{\mathrm{bc}}$ & $23.33 \pm 0.62^{\mathrm{c}}$ & $10.22 \pm 0.80^{\mathrm{bc}}$ \\
KmiSK16A004 & $19.85 \pm 3.89^{\mathrm{abc}}$ & $22.75 \pm 0.56^{\mathrm{c}}$ & $10.14 \pm 0.45^{\mathrm{bc}}$ \\
KmiSK16A006 & $19.78 \pm 3.78^{\mathrm{abc}}$ & $19.20 \pm 1.25^{\mathrm{b}}$ & $11.08 \pm 0.32^{\mathrm{cd}}$ \\
KmiICH17A011 & $19.76 \pm 1.77^{\mathrm{abc}}$ & $19.47 \pm 0.56^{\mathrm{b}}$ & $10.58 \pm 0.34^{\mathrm{bcd}}$ \\
KmiICH17A097 & $20.18 \pm 1.27^{\mathrm{bc}}$ & $19.20 \pm 0.88^{\mathrm{b}}$ & $9.13 \pm 0.34^{\mathrm{ab}}$ \\
KmiICH17A098 & $14.75 \pm 2.26^{\mathrm{ab}}$ & $18.38 \pm 0.13^{\mathrm{ab}}$ & $10.20 \pm 0.72^{\mathrm{bc}}$ \\
KmiRC20A118 & $25.40 \pm 1.82^{\mathrm{c}}$ & $26.83 \pm 1.52^{\mathrm{c}}$ & $13.24 \pm 0.99^{\mathrm{e}}$ \\
KmiRC20A119 & $21.15 \pm 2.35^{\mathrm{bc}}$ & $22.55 \pm 0.47^{\mathrm{c}}$ & $13.27 \pm 0.26^{\mathrm{e}}$ \\
KmiRC20A120 $^{\mathrm{b}}$ & $23.45 \pm 2.26^{\mathrm{c}}$ & $24.10 \pm 0.13^{\mathrm{c}}$ & $12.00 \pm 0.34^{\mathrm{de}}$
\end{tabular}

Mean values with the different letters (a-e) in superscript are significantly different according to Tukey's HSD test $(p<0.05)$.

\section{Conclusions}

This study confirmed our hypothesis that streptomycetes strains from the rhizosphere of oilseed rape showed PGPS traits and significantly promoted oilseed rape growth under controlled conditions. The most effective strain was KmiRC20A118, in which we recorded the highest production of IAA ( $\left.40 \mu \mathrm{g} \cdot \mathrm{mL}^{-1}\right)$; it produced siderophores and $\mathrm{HCN}$ and had a low phosphate solubility index, significantly affecting the total weight of fresh oilseed rape plants, with an increase of up to $68.45 \%$ compared to the control. We propose these strains for further testing in field experiments as a potential fertiliser and biostimulant for oilseed rape.

Author Contributions: Conceptualisation, R.C., N.L., S.J. and J.M. (Jana Maková), J.M. (Juraj Medo); methodology, R.C., N.L. and J.P.; formal analysis, R.C and S.J.; writing—original draft preparation, R.C.; supervision, S.J. and J.M. (Jana Maková); funding acquisition, L.D. All authors have read and agreed to the published version of the manuscript. 
Funding: This publication was supported by the Operational Program Integrated Infrastructure within the project: Demand-driven research for sustainable and innovative food, Drive4SIFood 313011V336, co-financed by the European Regional Development Fund.

Institutional Review Board Statement: Not applicable.

Informed Consent Statement: Not applicable.

Data Availability Statement: All data of this study are available from the authors upon request.

Acknowledgments: We thank the AgroBioTech Research Center, which provided us with cultivation chambers for growing plants.

Conflicts of Interest: The authors declare no conflict of interest.

\section{References}

1. Arvin, P.; Azizi, M.; Firuzeh, R. Study of dry matter partitioning into leaf, stem and pod at different oilseed rape cultivars. Int. J. Biosci. 2014, 4, 243-248. [CrossRef]

2. Friedt, W.; Snowdon, R. Oilseed rape. In Oil Crops; Springer: New York, NY, USA, 2009; pp. 91-126. [CrossRef]

3. Arvin, P.; Vafa Bakhsh, J. Study of drought and plant growth promoting rhizobacteria (PGPR) on radiation use efficiency and dry matter partitioning into pod in different cultivars of oilseed rape (Brassica napus L.). J. Agroecol. 2016, 8, $134-152$.

4. Snowdon, R.; Lühs, W.; Friedt, W. Oilseed rape. In Oilseeds; Springer: Berlin/Heidelberg, Germany, 2007; pp. 55-114. [CrossRef]

5. Rybakova, D.; Mancinelli, R.; Wikström, M.; Birch-Jensen, A.-S.; Postma, J.; Ehlers, R.-U.; Goertz, S.; Berg, G. The structure of the Brassica napus seed microbiome is cultivar-dependent and affects the interactions of symbionts and pathogens. Microbiome 2017, 5, 1-16. [CrossRef] [PubMed]

6. Mendes, R.; Kruijt, M.; De Bruijn, I.; Dekkers, E.; Van Der Voort, M.; Schneider, J.H.M.; Piceno, Y.M.; DeSantis, T.Z.; Andersen, G.L.; Bakker, P.A.H.M.; et al. Deciphering the Rhizosphere Microbiome for Disease-Suppressive Bacteria. Science 2011, 332, 1097-1100. [CrossRef]

7. Janssen, P.H.; Starkenburg, S.R.; Chain, P.S.G.; Sayavedra-Soto, L.A.; Hauser, L.; Land, M.L.; Larimer, F.W.; Malfatti, S.A.; Klotz, M.G.; Bottomley, P.J.; et al. Identifying the Dominant Soil Bacterial Taxa in Libraries of 16S rRNA and 16S rRNA Genes. Appl. Environ. Microbiol. 2006, 72, 2050-2063. [CrossRef] [PubMed]

8. Pérez-Montaño, F.; Alias-Villegas, C.; Bellogín, R.; del Cerro, P.; Espuny, M.; Jiménez-Guerrero, I.; López-Baena, F.; Ollero, F.; Cubo, T. Plant growth promotion in cereal and leguminous agricultural important plants: From microorganism capacities to crop production. Microbiol. Res. 2014, 169, 325-336. [CrossRef] [PubMed]

9. Olanrewaju, O.S.; Babalola, O.O. Streptomyces: Implications and interactions in plant growth promotion. Appl. Microbiol. Biotechnol. 2019, 103, 1179-1188. [CrossRef]

10. Viaene, T.; Langendries, S.; Beirinckx, S.; Maes, M.; Goormachtig, S. Streptomyces 669 as a plant's best friend? FEMS Microbiol. Ecol. 2016, 92, fiw119. [CrossRef]

11. Xue, L.; Xue, Q.; Chen, Q.; Lin, C.; Shen, G.; Zhao, J. Isolation and evaluation of rhizosphere actinomycetes with potential application for biocontrol of Verticillium wilt of cotton. Crop. Prot. 2013, 43, 231-240. [CrossRef]

12. Ahmad, S.; Daur, I.; Al-Solaimani, S.G.; Mahmood, S.; Bakhashwain, A.A.; Madkour, M.H.; Yasir, M. Effect of rhizobacteria inoculation and humic acid application on canola (Brassica napus L.) crop. Pak. J. Bot. 2016, 48, 2109-2120.

13. Valetti, L.; Iriarte, L.; Fabra, A. Growth promotion of rapeseed (Brassica napus) associated with the inoculation of phosphate solubilizing bacteria. Appl. Soil Ecol. 2018, 132, 1-10. [CrossRef]

14. Nejad, P.; Johnson, P.A. Endophytic bacteria induce growth promotion and wilt disease suppression in oilseed rape and tomato. Biol. Control 2000, 18, 208-215. [CrossRef]

15. Cheng, G.; Huang, Y.; Yang, H.; Liu, F. Streptomyces felleus YJ1: Potential biocontrol agents against the sclerotinia stem rot (Sclerotinia sclerotiorum) of oilseed rape. J. Agric. Sci. 2014, 6, 91. [CrossRef]

16. Wonglom, P.; Suwannarach, N.; Lumyong, S.; Ito, S.I.; Matsui, K.; Sunpapao, A. Streptomyces angustmyceticus NR8-2 as a potential microorganism for the biological control of leaf spots of Brassica rapa subsp. pekinensis caused by Colletotrichum sp. and Curvularia lunata. Biol. Control 2019, 138, 104046. [CrossRef]

17. Etesami, H.; Mirsyed Hosseini, H.; Alikhani, H.A. In planta selection of plant growth promoting endophytic bacteria for rice (Oryza sativa L.). J. Soil Sci. Plant Nutr. 2014, 14, 491-503. [CrossRef]

18. Poosarla, A.; Krishna, R.M. Isolation of potent antibiotic producing Actinomycetes from marine sediments of Andaman and Nicobar Marine Islands. J. Microbiol. Antimicrob. 2013, 5, 6-12. [CrossRef]

19. Shirling, E.B.; Gottlieb, D. Methods for characterization of Streptomyces species1. Internat. Int. J. Syst. Bacteriol. 1966, 16, 313-340. [CrossRef]

20. Cazin, J.; Wiemer, D.F.; Howard, J.J. Isolation, growth characteristics, and long-term storage of fungi cultivated by attine ants. Appl. Environ. Microbiol. 1989, 55, 1346-1350. [CrossRef]

21. Lane, D.J. 16S/23S rRNA sequencing. In Nucleic Acid Techniques in Bacterial Systematics; John Wiley \& Sons, Inc.: New York, NY, USA, 1991; pp. 115-175. 
22. Saitou, N.; Nei, M. The neighbor-joining method: A new method for reconstructing phylogenetic trees. Mol. Biol. Evol. 1987, 4, 406-425. [CrossRef]

23. Tamura, K.; Peterson, D.; Peterson, N.; Stecher, G.; Nei, M.; Kumar, S. MEGA5: Molecular evolutionary genetics analysis using maximum likelihood, evolutionary distance, and maximum parsimony methods. Mol. Biol. Evol. 2011, 28, 2731-2739. [CrossRef] [PubMed]

24. Gordon, S.A.; Weber, R.P. Colorimetric estimation of indoleacetic acid. Plant Physiol. 1951, 26, 192-195. [CrossRef]

25. Schwyn, B.; Neilands, J.B. Universal chemical assay for the detection and determination of siderophores. Anal. Biochem. 1987, 160, 47-56. [CrossRef]

26. Gupta, R.; Singal, R.; Shankar, A.; Kuhad, R.C.; Saxena, R.K. A modified plate assay for screening phosphate solubilizing microorganisms. J. Gen. Appl. Microbiol. 1994, 40, 255-260. [CrossRef]

27. Kumar, V.; Narula, N. Solubilization of inorganic phosphates and growth emergence of wheat as affected by Azotobacter chroococcum mutants. Biol. Fertil. Soils 1999, 28, 301-305. [CrossRef]

28. Lorck, H. Production of hydrocyanic acid by bacteria. Physiol. Plant. 1948, 1, 142-146. [CrossRef]

29. Anwar, S.; Ali, B.; Sajid, I. Screening of rhizospheric actinomycetes for various in-vitro and in-vivo plant growth promoting (PGP) traits and for agroactive compounds. Front. Microbiol. 2016, 7, 1334. [CrossRef] [PubMed]

30. Etesami, H.; Alikhani, H.A. Rhizosphere and endorhiza of oilseed rape (Brassica napus L.) plant harbor bacteria with multifaceted beneficial effects. Biol. Control 2016, 94, 11-24. [CrossRef]

31. Li, X.J.; Tian, B.M.; Fan, X.F.; Shi, G.Y.; Song, Z.; Pei, Z.Q.; Gao, S.G. Optimization of seed sterilization conditions for aseptic seedling on Brassica napus L. J. Henan Agric. Sci. 2009, 6, 35.

32. Van Der Wolf, J.M.; Van Beckhoven, J.R.C.M.; Hukkanen, A.; Karjalainen, R.; Müller, P. Fate of Clavibacter michiganensis ssp. sepedonicus, the causal organism of bacterial ring rot of potato, in weeds and field crops. J. Phytopathol. 2005, 153, 358-365. [CrossRef]

33. Liu, D.; Yan, R.; Fu, Y.; Wang, X.; Zhang, J.; Xiang, W. Antifungal, plant growth-promoting, and genomic properties of an endophytic actinobacterium Streptomyces sp. NEAU-S7GS2. Front. Microbiol. 2019, 10, 2077. [CrossRef]

34. Islam, M.; Lee, B.R.; Park, S.H.; La, V.H.; Bae, D.W.; Kim, T.H. Cultivar variation in hormonal balance is a significant determinant of disease susceptibility to Xanthomonas campestris pv. campestris in Brassica napus. Front. Plant Sci. 2017, 8, 2121. [CrossRef]

35. Wang, Z.; Bao, L.L.; Zhao, F.Y.; Tang, M.Q.; Chen, T.; Li, Y.; Tan, X.L. BnaMPK3 is a key regulator of defense responses to the devastating plant pathogen Sclerotinia sclerotiorum in oilseed rape. Front. Plant Sci. 2019, 10, 91. [CrossRef] [PubMed]

36. Fitt, B.D.; Brun, H.; Barbetti, M.J.; Rimmer, S.R. World-wide importance of phoma stem canker (Leptosphaeria maculans and L. biglobosa) on oilseed rape (Brassica napus). In Sustainable Strategies for Managing Brassica Napus (Oilseed Rape) Resistance to Leptosphaeria maculans (Phoma Stem Canker); Springer: Dordrecht, The Netherlands, 2006; pp. 3-15. [CrossRef]

37. Peng, F.; Zhang, M.Y.; Hou, S.Y.; Chen, J.; Wu, Y.Y.; Zhang, Y.X. Insights into Streptomyces spp. isolated from the rhizospheric soil of Panax notoginseng: Isolation, antimicrobial activity and biosynthetic potential for polyketides and non-ribosomal peptides BMC Microbiol. 2020, 20, 1-16. [CrossRef] [PubMed]

38. Gkarmiri, K.; Mahmood, S.; Ekblad, A.; Alström, S.; Högberg, N.; Finlay, R. Identifying the active microbiome associated with roots and rhizosphere soil of oilseed rape. Appl. Environ. Microbiol. 2017, 83, e01938-17. [CrossRef] [PubMed]

39. Hu, J.; Wei, Z.; Kowalchuk, G.A.; Xu, Y.; Shen, Q.; Jousset, A. Rhizosphere microbiome functional diversity and pathogen invasion resistance build up during plant development. Environ. Microbiol. 2020, 22, 5005-5018. [CrossRef]

40. Wink, J.M. DSMZ-Compendium of Actinobacteria. 2021. Available online: https://www.dsmz.de/fileadmin/user_upload/ Collection_allg/Export_Wink_Liste_2016.pdf (accessed on 10 February 2021).

41. Charousová, I.; Steinmetz, H.; Medo, J.; Javoreková, S.; Wink, J. Characterization of antimycins-producing streptomycete strain VY46 isolated from slovak soil. Braz. Arch. Biol. Technol. 2016, 59, 59. [CrossRef]

42. Vurukonda, S.S.K.P.; Vardharajula, S.; Shrivastava, M.; SkZ, A. Enhancement of drought stress tolerance in crops by plant growth promoting rhizobacteria. Microbiol. Res. 2016, 184, 13-24. [CrossRef]

43. Islam, M.R.; Jeong, Y.T.; Ryu, Y.J.; Song, C.H.; Lee, Y.S. Isolation, identification and optimal culture conditions of Streptomyces albidoflavus C247 producing antifungal agents against Rhizoctonia solani AG2-2. Mycobiology 2009, 37, 114-120. [CrossRef]

44. Jain, P.K.; Jain, P.C. Isolation, characterization and antifungal activity of Streptomyces sampsonii GS 1322. Indian J. Exp. Boil. 2007, 45, 203-206.

45. Salwan, R.; Sharma, V.; Sharma, A.; Singh, A. Molecular imprints of plant beneficial Streptomyces sp. AC30 and AC40 reveal differential capabilities and strategies to counter environmental stresses. Microbiol. Res. 2020, 235, 126449. [CrossRef]

46. Hao, L.; Zheng, X.; Wang, Y.; Li, S.; Shang, C.; Xu, Y. Inhibition of tomato early blight disease by culture extracts of a Streptomyces puniceus isolate from mangrove soil. Phytopathology 2019, 109, 1149-1156. [CrossRef] [PubMed]

47. Reverchon, F.; García-Quiroz, W.; Guevara-Avendaño, E.; Solís-García , I.A.; Ferrera-Rodr Guez, O.; Lorea-Hernández, F. Antifungal potential of Lauraceae rhizobacteria from a tropical montane cloud forest against Fusarium spp. Braz. J. Microbiol. 2019, 50, 583-592. [CrossRef] [PubMed]

48. Javoreková, S.; Kovácsová, S.; Medo, J.; Maková, J.; Petrová, J.; Hleba, L.; Košt’alová, D.; Cinkocki, R. Soil amended with organic fertilizers as a source of actinomycetes with high potential as biocontrol agents. J. Microbiol. Biotechnol. Food Sci. 2019, 8, 1352-1359. [CrossRef] 
49. Charousová, I.; Javoreková, S.; Wink, J. Isolation and characterization of Streptomyces rishiriensis (VY31) with antibiotic activity against various pathogenic microorganisms. J. Microbiol. Biotechnol. Food Sci. 2015, 4, 23-27. [CrossRef]

50. Singh, S.P.; Gaur, R. Evaluation of antagonistic and plant growth promoting activities of chitinolytic endophytic actinomycetes associated with medicinal plants against Sclerotium rolfsii in chickpea. J. Appl. Microbiol. 2016, 121, 506-518. [CrossRef]

51. Khamna, S.; Yokota, A.; Lumyong, S. Actinomycetes isolated from medicinal plant rhizosphere soils: Diversity and screening of antifungal compounds, indole-3-acetic acid and siderophore production. World J. Microbiol. Biotechnol. 2008, 25, 649-655. [CrossRef]

52. Poomthongdee, N.; Duangmal, K.; Pathom-Aree, W. Acidophilic actinomycetes from rhizosphere soil: Diversity and properties beneficial to plants. J. Antibiot. 2015, 68, 106-114. [CrossRef]

53. Park, H.M.; Kim, B.G.; Chang, D.; Malla, S.; Joo, H.S.; Kim, E.J.; Kim, P. IGenome-based cryptic gene discovery and functional identification of NRPS siderophore peptide in Streptomyces peucetius. Appl. Microbiol. Biotechnol. 2013, 97, 1213-1222. [CrossRef]

54. Xu, L.; Ren, L.; Chen, K.; Liu, F.; Fang, X. Putative role of IAA during the early response of Brassica napus L. to Plasmodiophora brassicae. Eur. J. Plant Pathol. 2016, 145, 601-613. [CrossRef]

55. El-Tarabily, K.A. Promotion of tomato (Lycopersicon esculentum Mill.) plant growth by rhizosphere competent 1-aminocyclopropane1-carboxylic acid deaminase-producing streptomycete actinomycetes. Plant Soil 2008, 308, 161-174. [CrossRef]

56. Narayana, K.J.; Prabhakar, P.; Vijayalakshmi, M.U.V.V.A.; Venkateswarlu, Y.; Krishna, P.S. Biological activity of phenylpropionic acid isolated from a terrestrial Streptomycetes. Pol. J. Microbiol. 2007, 56, 191. [PubMed]

57. Khamna, S.; Yokota, A.; Peberdy, J.F.; Lumyong, S. Indole-3-acetic acid production by Streptomyces sp. isolated from some Thai medicinal plant rhizosphere soils. EurAsian J. Biosci. 2010, 4, 23-32. [CrossRef]

58. Setyaningsih, W.; Saputro, I.E.; Palma, M.; Barroso, C.G. Optimization of the ultrasound-assisted extraction of tryptophan and its derivatives from rice (Oryza sativa) grains through a response surface methodology. J. Cereal Sci. 2017, 75, 192-197. [CrossRef]

59. Myo, E.M.; Ge, B.; Ma, J.; Cui, H.; Liu, B.; Shi, L.; Zhang, K. Indole-3-acetic acid production by Streptomyces fradiae NKZ-259 and its formulation to enhance plant growth. BMC Microbiol. 2019, 19, 1-14. [CrossRef] [PubMed]

60. Sridevi, M.; Mallaiah, K.V. Bioproduction of indole acetic acid by Rhizobium strains isolated from root nodules of green manure crop, Sesbania sesban (L.) Merr. Iran. J. Biotechnol. 2007, 5, 178-182.

61. Sarwar, M.; Kremer, R.J. Determination of bacterially derived auxins using a microplate method. Lett. Appl. Microbiol. 1995, 20, 282-285. [CrossRef]

62. Abd-Alla, M.H.; El-Sayed, A.; Rasmey, A.H.M. Indole-3-acetic acid (IAA) production by Streptomyces atrovirens isolated from rhizospheric soil in Egypt. J. Biol. Earth Sci. 2013, 3, 182-193.

63. Tsavkelova, E.A.; Klimova, S.Y.; Cherdyntseva, T.A.; Netrusov, A.I. Microbial producers of plant growth stimulators and their practical use: A review. Appl. Biochem. Microbiol. 2006, 42, 117-126. [CrossRef]

64. Subramaniam, G.; Thakur, V.; Saxena, R.K.; Vadlamudi, S.; Purohit, S.; Kumar, V.; Varshney, R.K. Complete genome sequence of sixteen plant growth promoting Streptomyces strains. Sci. Rep. 2020, 10, 1-13. [CrossRef]

65. Jog, R.; Nareshkumar, G.; Rajkumar, S. Plant growth promoting potential and soil enzyme production of the most abundant Streptomyces spp. from wheat rhizosphere. J. Appl. Microbiol. 2012, 113, 1154-1164. [CrossRef]

66. Challis, G.L.; Hopwood, D.A. Synergy and contingency as driving forces for the evolution of multiple secondary metabolite production by Streptomyces species. Proc. Natl. Acad. Sci. USA 2003, 100, 14555-14561. [CrossRef] [PubMed]

67. Nakouti, I.; Sihanonth, P.; Hobbs, G. A new approach to isolating siderophore-producing actinobacteria. Lett. Appl. Microbiol. 2012, 55, 68-72. [CrossRef] [PubMed]

68. Sreevidya, M.; Gopalakrishnan, S.; Kudapa, H.; Varshney, R.K. Exploring plant growth-promotion actinomycetes from vermicompost and rhizosphere soil for yield enhancement in chickpea. Braz. J. Microbiol. 2016, 47, 85-95. [CrossRef] [PubMed]

69. Yadav, A.N.; Verma, P.; Kumar, S.; Kumar, V.; Kumar, M.; Sugitha, T.C.K.; Dhaliwal, H.S. Actinobacteria from rhizosphere: Molecular diversity, distributions, and potential biotechnological applications. In New and Future Developments in Microbial Biotechnology and Bioengineering; Elsevier: Amsterdam, The Netherlands, 2018; pp. 13-41. [CrossRef]

70. Chaiharn, M.; Theantana, T.; Pathom-Aree, W. Evaluation of biocontrol activities of Streptomyces spp. against rice blast disease fungi. Pathogens 2020, 9, 126. [CrossRef] [PubMed]

71. Passari, A.K.; Mishra, V.K.; Saikia, R.; Gupta, V.K.; Singh, B.P. Isolation, abundance and phylogenetic affiliation of endophytic actinomycetes associated with medicinal plants and screening for their in vitro antimicrobial biosynthetic potential. Front. Microbiol. 2015, 6, 273. [CrossRef]

72. Hamdali, H.; Hafidi, M.; Virolle, M.J.; Ouhdouch, Y. Growth promotion and protection against damping-off of wheat by two rock phosphate solubilizing actinomycetes in a P-deficient soil under greenhouse conditions. Appl. Soil Ecol. 2008, 40, 510-517. [CrossRef]

73. Hanif, K.; Hameed, S.; Imran, A.; Naqqash, T.; Shahid, M.; Van Elsas, J.D. Isolation and characterization of a $\beta$-propeller gene containing phosphobacterium Bacillus subtilis strain KPS-11 for growth promotion of potato (Solanum tuberosum L.). Front. Microbiol. 2015, 6, 583. [CrossRef]

74. Nandimath, A.P.; Karad, D.D.; Gupta, S.G.; Kharat, A.S. Consortium inoculum of five thermo-tolerant phosphate solubilizing Actinomycetes for multipurpose biofertilizer preparation. Iran. J. Microbiol. 2017, 9, 295. 
75. Boubekri, K.; Soumare, A.; Mardad, I.; Lyamlouli, K.; Hafidi, M.; Ouhdouch, Y.; Kouisni, L. The screening of potassium-and phosphate-solubilizing actinobacteria and the assessment of their ability to promote wheat growth parameters. Microorganisms 2021, 9, 470. [CrossRef]

76. Nautiyal, C.S. An efficient microbiological growth medium for screening phosphate solubilizing microorganisms. FEMS Microbiol. Lett. 1999, 170, 265-270. [CrossRef]

77. Munir, I.; Bano, A.; Faisal, M. Impact of phosphate solubilizing bacteria on wheat (Triticum aestivum) in the presence of pesticides. Braz. J. Biol. 2019, 79, 29-37. [CrossRef] [PubMed]

78. Suleman, M.; Yasmin, S.; Rasul, M.; Yahya, M.; Atta, B.M.; Mirza, M.S. Phosphate solubilizing bacteria with glucose dehydrogenase gene for phosphorus uptake and beneficial effects on wheat. PLOS ONE 2018, 13, e0204408. [CrossRef] [PubMed]

79. Shahzad, S.M.; Arif, M.S.; Riaz, M.; Iqbal, Z.; Ashraf, M. PGPR with varied ACC-deaminase activity induced different growth and yield response in maize (Zea mays L.) under fertilized conditions. Eur. J. Soil Biol. 2013, 57, 27-34. [CrossRef]

80. Mehta, P.; Walia, A.; Kulshrestha, S.; Chauhan, A.; Shirkot, C.K. Efficiency of plant growth-promoting P-solubilizing Bacillus circulans CB7 for enhancement of tomato growth under net house conditions. J. Basic Microbiol. 2015, 55, 33-44. [CrossRef] [PubMed]

81. Habibi, S.; Djedidi, S.; Prongjunthuek, K.; Mortuza, M.F.; Ohkama-Ohtsu, N.; Sekimoto, H.; Yokoyoma, T. Physiological and genetic characterization of rice nitrogen fixer PGPR isolated from rhizosphere soils of different crops. Plant Soil 2014, 379, 51-66. [CrossRef]

82. Zahid, M. Isolation and identification of indigenous plant growth promoting rhizobacteria from Himalayan region of Kashmir and their effect on improving growth and nutrient contents of maize (Zea mays L.). Front. Microbiol. 2015, 6, 207. [CrossRef]

83. Lin, L.; Xu, X. Indole-3-acetic acid production by endophytic Streptomyces sp. En-1 isolated from medicinal plants. Curr. Microbiol. 2013, 67, 209-217. [CrossRef]

84. Palaniyandi, S.A.; Damodharan, K.; Yang, S.H.; Suh, J.W. Streptomyces sp. strain PGPA39 alleviates salt stress and promotes growth of 'Micro Tom' tomato plants. J. Appl. Microbiol. 2014, 117, 766-773. [CrossRef]

85. Gopalakrishnan, S.; Vadlamudi, S.; Bandikinda, P.; Sathya, A.; Vijayabharathi, R.; Rupela, O.; Varshney, R.K. Evaluation of Streptomyces strains isolated from herbal vermicompost for their plant growth-promotion traits in rice. Microbiol. Res. 2014, 169, 40-48. [CrossRef]

86. Jog, R.; Pandya, M.; Nareshkumar, G.; Rajkumar, S. Mechanism of phosphate solubilization and antifungal activity of Streptomyces spp. isolated from wheat roots and rhizosphere and their application in improving plant growth. Microbiology 2014, 160, 778-788. [CrossRef] [PubMed]

87. Belimov, A.A.; Dodd, I.C.; Safronova, V.I.; Shaposhnikov, A.I.; Azarova, T.S.; Makarova, N.M.; Tikhonovich, I.A. Rhizobacteria that produce auxins and contain 1-amino-cyclopropane-1-carboxylic acid deaminase decrease amino acid concentrations in the rhizosphere and improve growth and yield of well-watered and water-limited potato (Solanum tuberosum). Ann. Appl. Biol. 2015, 167, 11-25. [CrossRef]

88. Mahmood, A.; Turgay, O.C.; Farooq, M.; Hayat, R. Seed biopriming with plant growth promoting rhizobacteria: A review. FEMS Microbiol. Ecol. 2016, 92, fiw112. [CrossRef] [PubMed]

89. Campanoni, P.; Nick, P. Auxin-dependent cell division and cell elongation. 1-Naphthaleneacetic acid and 2, 4-dichlorophenoxyacetic acid activate different pathways. Plant Physiol. 2005, 137, 939-948. [CrossRef]

90. Kiani, M.Z.; Sultan, T.; Ali, A.; Rizvi, Z.F. Application of ACC-deaminase containing PGPR improves sunflower yield under natural salinity stress. Pak. J. Bot. 2016, 48, 53-56.

91. Zamioudis, C.; Mastranesti, P.; Dhonukshe, P.; Blilou, I.; Pieterse, C.M. Unraveling root developmental programs initiated by beneficial Pseudomonas spp. bacteria. Plant Physiol. 2013, 162, 304-318. [CrossRef] [PubMed]

92. Spaepen, S.; Bossuyt, S.; Engelen, K.; Marchal, K.; Vanderleyden, J. Phenotypical and molecular responses of Arabidopsis thaliana roots as a result of inoculation with the auxin-producing bacterium Azospirillum brasilense. New Phytol. 2014, 201, 850-861. [CrossRef]

93. Verma, J.P.; Yadav, J.; Tiwari, K.N.; Kumar, A. Effect of indigenous Mesorhizobium spp. and plant growth promoting rhizobacteria on yields and nutrients uptake of chickpea (Cicer arietinum L.) under sustainable agriculture. Ecol. Eng. 2013, 51, 282-286. [CrossRef] 